\title{
NOTE
}

\section{Fission track dating of copper ore formations of Khetri area, Rajasthan State (India)*}

\author{
SURINDER SingH and H. S. VIRK \\ Department of Physics, Guru Nanak Dev University, Amritsar - 143005, India
}

(Received November 13, 1979; Accepted February 4, 1980)

\begin{abstract}
From the fission track age determination of garnet occurring in copper ore deposits of Khetri copper belt, Rajasthan, it has been possible to reveal the metamorphism of copper ore formations of the area. The fission track age of $831 \pm 132 \mathrm{~m} . \mathrm{y}$. for garnet suggests that the copper ore formations in the region were subjected to a metamorphic episode which coincides with the Delhi Cycle.
\end{abstract}

\section{INTRODUCTION}

Fission track (f.t.) technique developed by Price and WALKer (1963) is an established method of dating terrestrial and extraterrestrial materials (FLEISCHER et al., 1975). It is used in the present work for dating metamorphism of the copper ore formations of Khetri copper belt in Rajasthan.

Of gangue minerals which form simultaneously with the ore deposits, garnet is likely to prove the most useful in fission track dating. Another promising use of garnets in fission track geochronology is in dating skarns of ore deposits.

Garnet has not as yet been used in this way. BANKS and StUCKLESS (1973) used garnets and other minerals in the fission track dating of intrusive rocks believed to have formed simultaneously with a porphyry copper deposit.

The garnet samples studied have been collected from the Khetri copper belt (Fig. 1) in Rajasthan which extends for about $80 \mathrm{~km}$ from Singhana (Jhunjhunu district) to Raghunathgarh (Sikar district) and comprises three highly mineralised sections - Madhan, Kolihan and Akhwali. Mineralization has taken place in the phyllites, schists and slates of Delhi system. The ore localisation in this belt is thought to be primarily controlled by structural features (shear zones and fractures). The ore bodies occur as enechelon ore - shoots, stringers and also as disseminations. In this belt, the Kolihan and Khetri prospects are in chlorite schists while the host rocks around Dhanota are the phyllites, phyllitic quartzites and quartz schists. The Madan and Kudhan prospects are in garnet chlorite shists, silicified chlorite schists and phyllites. The country rocks around Dariba are phyllites, biotite schists and quartzites. In Khetri belt, pyrite, pyrrhotite and chalcopyrite are the main sulphide minerals along with the cobalt sulphides (cobaltite and danaite). The secondary copper minerals reported are azurite, malachite, covellite and chalcocite. Evidences of wall-rock alterations are reported to be mainly silicifications and at places also chloritization, biotitization and sericitization in the host rocks.

\section{Experimental Procedure and Results}

Garnet samples were separated in the form of small grains from the host rock containing copper ore. These grains were fixed on glass 


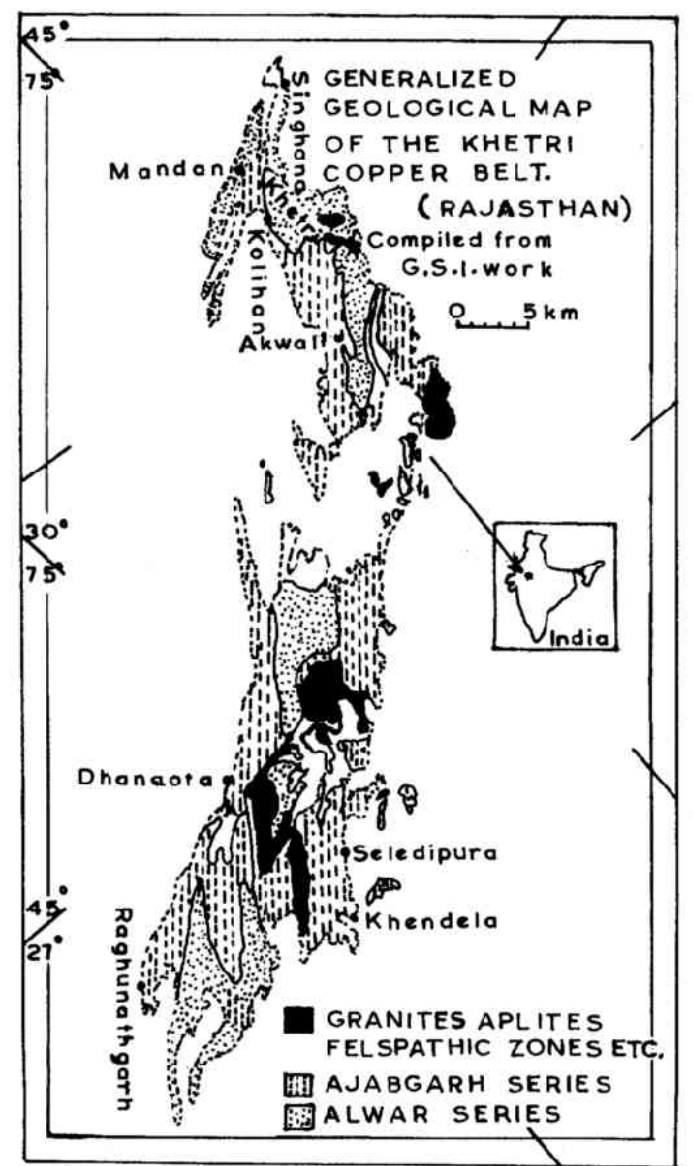

Fig. 1. Geological map of Khetri copper belt, Rajasthan.

slide and were ground with emery powder of mesh size varying from $100 \mu \mathrm{m}$ to $60 \mu \mathrm{m}$ and were polished with cerium oxide powder. Final lap of polishing was given with $1 \mu \mathrm{m}$ diamond paste on chamois leather. The samples were then etched with $50 \mathrm{~N} \mathrm{NaOH}$ at a temperature of $150^{\circ} \mathrm{C}$ for $90 \mathrm{~min}$ using the reflux condenser assembly and a constant temperature bath. After etching, the fossil tracks are counted under a binocular Carl Zeiss microscope using a magnification of $1,500 x$.

Garnet samples were got irradiated with $10^{17}$ (nvt) dose of thermal neutrons from CIRUS Reactor of B.A.R.C., Trombay. These samples were again prepared and etched under identical conditions as for fossil tracks. The induced fission tracks (Fig. 2) were counted as before.
Samples showing tracks due to heterogeneous distribution of uranium (Fig. 3) were rejected.

The f.t. ages are calculated by using the simplified version of the formula (VIRK and KoUL, 1974, SINGH and VIRK, 1978a)

$$
\mathrm{T}=6.57 \times 10^{9} \ln \left(1+9.25 \times 10^{-18} \times \frac{\rho_{\mathrm{s}}}{\rho_{\mathrm{i}}} \times \mathrm{F}\right)
$$

where $\rho_{\mathrm{S}}$ and $\rho_{\mathrm{i}}$ are the fossil and induced track densities respectively and $\mathrm{F}$ is the total thermal neutron dose. The values of the constants used for getting equation (1) are the same as reported elsewhere (VIRK and SINGH, 1977). The value of $\mathrm{F}$ is determined by irradiating a calibrated glass slide along with garnet samples (FLEISCHER et al., 1965).

The formula for U. conc. measurements is given by NAGPAUL (1974). In case of garnet (Fe $\mathrm{Ca} \mathrm{Mg} \mathrm{Mn})_{3}(\mathrm{AlFe})_{2}\left(\mathrm{SiO}_{4}\right)_{3}$, Ro (the total range

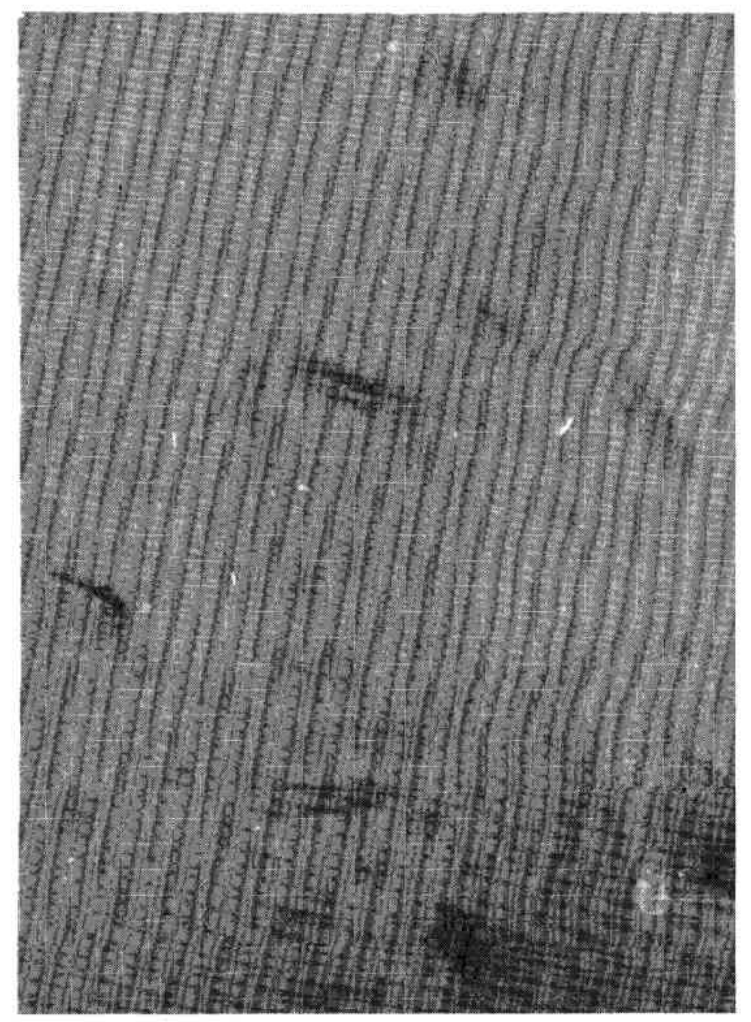

Fig. 2. Microphotograph of induced fission tracks in garnet from Khetri copper belt, showing homogeneous distribution of uranium. 


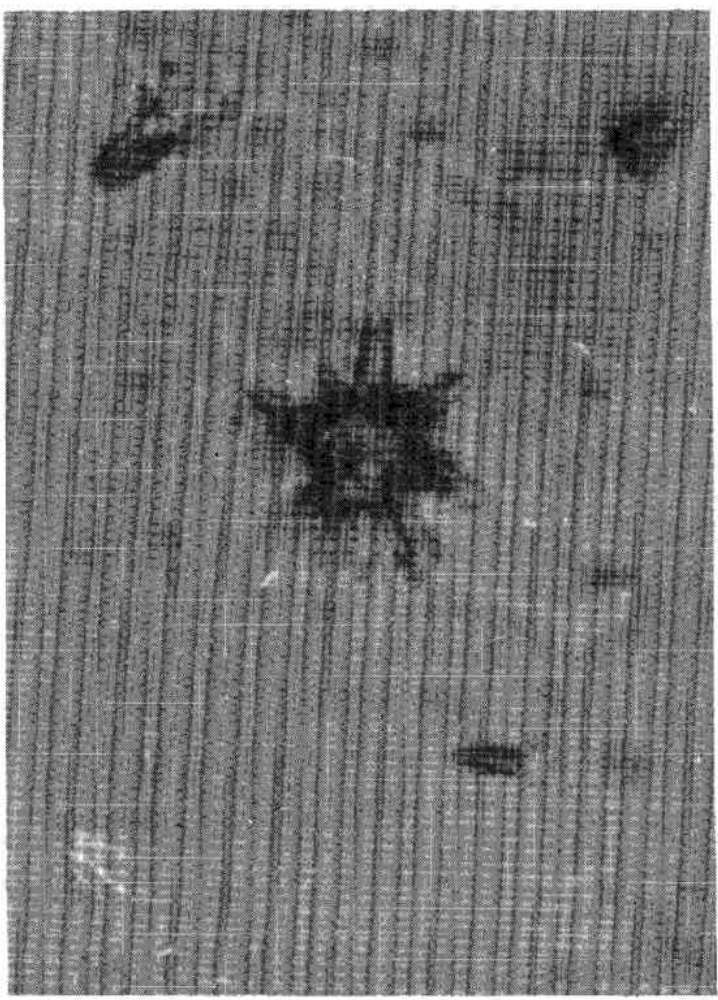

Fig. 3. Microphotograph of induced fission tracks in garnet from Khetri Copper belt, showing heterogenous distribution of uranium.

of both prongs of a fission event) $=13.4 \mu \mathrm{m}$ and $\mathrm{d}$ (density) $=3.1 \mathrm{~g} / \mathrm{cm}^{3}$, therefore, the concentration of uranium by weight, is given by:

$$
\mathrm{C}_{\mathrm{w}}=4.5 \times 10^{4} \times \frac{\rho_{\mathrm{i}}}{\mathrm{F}} \mathrm{gm} / \mathrm{gm}
$$

The f.t. ages and $U$. conc. in garnet samples calculated by using equations (1) and (2) are, summarized in Table 1 . The errors shown in the results are $1 \sigma$ (standard) errors calculated on the basis of number of fossil and induced tracks counted in the specimens.

\section{Discussion}

Three orogenic cycles namely Banded gneissic complex, Aravalli cycle and Delhi cycle have been found to affect most of the rocks of Rajasthan according to radiometric data collected by various authors (HoLmes, 1955,
SARKAR et al., 1964 and VINOGRADOV et al., 1964). A detailed geological description of these cycles is reported by SINGH and VIRK (1978b).

Garnet samples from the copper ore region of Khetri Copper belt have yielded a mean f.t. age of $831 \pm 132 \mathrm{~m} . \mathrm{y}$. suggesting the occurrence of last major metamorphism of copper ore formation in the belt corresponding to Delhi system. Aravalli and Banded gneissic group cycles have not left any residual record of their occurrence in the form of fossil fission tracks in the area.

The f.t. technique is based on the registration of fossil fission tracks in minerals which are annealed at high temperatures obtainable during the orogenic metamorphic cycles thus completely rejuvenating the minerals and resetting the geological clock. Therefore, the f.t. ages reported in this study are neither the mineralisation ages nor the deposition ages but they reveal the occurrence of last major metamorphic episode in the copper belt.

The uranium content of the accessory minerals associated with copper ore formations depends upon the nature of the minerals. It is too low in quartz but quite high in uraninite. However, the garnet samples recorded a good number of induced fission tracks and the uranium concentration has thus been determined. The uranium distribution in accessory minerals can be helpful in delineating the mineralisation of ores and the technique can be used for solving the problem of origin and stratigraphy of banded copper ore formations in a region.

Garnet samples from pegmatitic mine of Narnaul district (Haryana) yield f.t. age of 749 $\pm 73 \mathrm{~m}$.y. which belongs to Delhi system but is less than that for garnet from copper ore formation of Khetri region. The uranium content of garnet from Khetri copper belt is comparatively more than that in garnet from Narnaul district of Haryana, suggesting thereby that the probability and concentration of uranium for exploration is more in copper ore mines than 
Table 1. Fission track data for garnets of Rajasthan and Haryana State (India)

\begin{tabular}{|c|c|c|c|c|c|}
\hline $\begin{array}{c}\text { Sample } \\
\text { location }\end{array}$ & $\begin{array}{c}\text { Lab symbol } \\
\text { of specimens } \\
\text { studied }\end{array}$ & $\begin{array}{l}\text { Fossil track } \\
\text { density } \\
\rho_{\mathrm{S}} / \mathrm{cm}^{2}\end{array}$ & $\begin{array}{c}\text { Induced track } \\
\text { density } \\
\rho_{\mathrm{i}} / \mathrm{cm}^{2}\end{array}$ & $\begin{array}{c}\text { Fission track } \\
\text { age (m.y.) } \\
\text { T }\end{array}$ & $\begin{array}{l}\text { U. Conc. } \\
\text { (gm/gm) } \\
\times 10^{-8}\end{array}$ \\
\hline \multirow{5}{*}{$\begin{array}{l}\text { Garnet, } \\
\text { Khetri Copper } \\
\text { Project, } \\
\text { Khetri, } \\
\text { Rajasthan }\end{array}$} & GKR -I & $\begin{array}{l}8600 \\
(43)^{*}\end{array}$ & $\begin{array}{c}63096 \\
(400)^{*}\end{array}$ & $831 \pm 133^{* * *}$ & 2.64 \\
\hline & GKR -II & $\begin{array}{c}8800 \\
(44)\end{array}$ & $\begin{array}{r}64561 \\
(409)\end{array}$ & $831 \pm 131$ & 2.70 \\
\hline & GKR -III & $\begin{array}{r}9000 \\
(45)\end{array}$ & $\begin{array}{r}65350 \\
(414)\end{array}$ & $839 \pm 132$ & 2.73 \\
\hline & GKR -IV & $\begin{array}{r}8600 \\
(43)\end{array}$ & $\begin{array}{r}64500 \\
(408)\end{array}$ & $814 \pm 131$ & 2.70 \\
\hline & GKR -V & $\begin{array}{r}9000 \\
(45)\end{array}$ & $\begin{array}{c}65298 \\
(413)\end{array}$ & $840 \pm 132$ & 2.73 \\
\hline \multirow{7}{*}{$\begin{array}{l}\text { Garnet, } \\
\text { Khatoli Ahear, } \\
\text { Narnaul, } \\
\text { Haryana }\end{array}$} & & & Mean & $831 \pm 132$ & 2.70 \\
\hline & GNH -I & $\begin{array}{l}5860 \\
(125)^{*}\end{array}$ & $\begin{array}{c}48044 \\
(885)^{*}\end{array}$ & $749 \pm 71^{* *}$ & 1.97 \\
\hline & GNH -II & $\begin{array}{l}5740 \\
(122)\end{array}$ & $\begin{array}{r}46666 \\
(858)\end{array}$ & $755 \pm 73$ & 1.92 \\
\hline & GNH -III & $\begin{array}{l}5635 \\
(120)\end{array}$ & $\begin{array}{r}46194 \\
(850)\end{array}$ & $749 \pm 73$ & 1.91 \\
\hline & GNH -IV & $\begin{array}{l}5540 \\
(117)\end{array}$ & $\begin{array}{r}45802 \\
(842)\end{array}$ & $743 \pm 73$ & 1.88 \\
\hline & GNH $-\mathrm{V}$ & $\begin{array}{l}5400 \\
(115)\end{array}$ & $\begin{array}{r}44268 \\
(814)\end{array}$ & $749 \pm 75$ & 1.82 \\
\hline & & & Mean & $749 \pm 73$ & 1.90 \\
\hline
\end{tabular}

* Brackets show the number of tracks counted i.e, $N_{s}, N_{i}$.

** $1 \sigma=\sqrt{\sigma_{s}^{2}+\sigma_{i}^{2}}, \quad \sigma_{s}=\frac{100}{\sqrt{N_{s}}}, \quad \sigma_{i}=\frac{100}{\sqrt{N_{i}}}$.

in pegmatitic mines. This is practically true as most of the uranium in India is being exploited from the copper ore mines.

As the tracks in garnets are stable even in the temperature range of $560^{\circ} \mathrm{C}$ (HAACK and POTTS, 1972, LAL et al., 1976) annealing correction to the fission track ages due to geothermal variations in the orogeny may be ignored.

Acknowledgements-The authors acknowledge the financial assistance of council of Scientific and Industrial Research, new Delhi. Thanks are due to S. BALBIR SINGH Suptdg. Mining Engg. Khetri Copper project, for help in collecting the samples.

\section{REFERENCES}

B ANKS, G. and STUCKLESS, J. S. (1973) Chronology of instrusion and ore deposition at Ray, Arizona: Part-II, Fission track ages. Econ. Geol. 68, 657664.

Fleischer, R. L., Price, P. B. and WAlker, R. M. (1965) Nuetron flux measurements by fission tracks in solids. Nucl. Sci. Eng. 22, 153-156.

Fleischer, R. L., Price, P. B. and W Alker, R. M. (1975) Nuclear tracks in solids, Principles and applications. University of California Press, Berkely.

HAAK, U. and PoTTS, M. J. (1972) Fission track annealing in garnet. Contr. Mineral. Petrol. 34, 343345.

Holmes, A. (1955) Dating the Precambrian of Peninsular India and Ceylon. Can. Geol. Ass. Proc. 7, 81-105.

NAGPAUL, K. K. (1974) Fission track ages of some muscovites of Nellore Mica Belt, Recent researches in geology, Hindustan Publishing, Delhi, 41-52.

Lal, N., NagPaUl, K. K. and Sharma, K. K. (1976) Fission track ages and uranium concentration in garnets of Rajasthan, India. Geol. Soc. Am. Bull. 87, 687-690.

PRICE, P. B. and WALKeR, R. M. (1963) Fossil tracks of charged particles in mica and the age of minerals. J. Geophys. Res. 68, 4847-4862.

Sarkar, S. N., PolKanov, A. A., Gerling, E. K. and CHUKROV, F. V. (1964) Precambrian geochronology of peninsular India. A synopsis. Sci. and Cult. Calcutta 30, 527-537.

SiNGH, S. and VIRK, H. S. (1978a) Fission track dat- 
ing and estimation of uranium in some garnets of Rajasthan (India). Nucl. Track Detection 2, 169171.

SINGH, S. and VIRK, H. S. (1978a) Fission track dating and uranium estimation in pegmatitic minerals of Rajasthan State (India). Geochem. J. 12, 271274.

Vinogradov, A. P., Tugarinov, A. ZhyKov, C., STAPPHIKOVA, N., BIBIKOVA, E. and KBORRE, K.
(1964) Geochronology of the Precambrian. Proc. 22nd Inst. Geol. Cong., N. Delhi, 10, 553-567.

VIRK, H. S. and KoUL, S. L. (1974) Fission track ages of some biotites of Bihar mica belt. Ind. $J$. Pure Appl. Phys. 12, 850-852.

VIRK, H. S. and SINGH, S. (1977) Fission track dating and uranium mineralization in pegmatites of Bhilwara area, Rajasthan State (India). Mineral $J$. 8, 263-271. 